\title{
高炉スラグ微粉末の活性度の新しい評価方法
}

\section{A NEW METHOD OF EVALUATING THE ACTIVITY OF GROUND GRANULATED BLAST-FURNACE SLAG}

\author{
近松竜一*・山本泰彦** \\ By Ryuichi CHIKAMATSU and Yasuhiko YAMAMOTO
}

\begin{abstract}
Mortar specimens for compressive strength tests were prepared using six kinds of ground granulated blast-furnace slags of various Blaine specific surface areas. Watercement ratio and sand-cement ratio of base mortar containing no ground slag were fixed at 0.50 and 2.50, respectively. Replacement ratios of cement by ground slag were set at 30,50 and $70 \%$ by volume. Both the preparation and moist-curing of the specimens were conducted at a constant temperature ; i. e., 5,10 , or $20^{\circ} \mathrm{C}$. The results of compressive strength test were analyzed to derive equations, by which the effects of each influential factor could be quantitatively evaluated. New two indices, which are independent on various factors, were proposed for evaluating the activity of ground slags.

Keywords : activity, ground slag, mortar, new indices, strength estimation
\end{abstract}

\section{1. 序}

コンクリートの品質改善を主たる目的として用いられ る高炉スラグ微粉末（以下，スラグ微粉末之略称）は, 同時に結合材としての役割も担っている.この結合材と しての役割の程度はスラグ微粉末の活性度に大きく依存 するので, スラグ微粉末の品質に関する各国の規格では, この活性度に対する規格值を設けており, その指標とし ては一般に活性度指数（SAI; Slag Activity Index）が 用いられている. 活性度指数は，「セメントの $50 \%$ をス ラグ微粉末で置換して造ったモルタル（置換率は, アメ リカ, 日本では重量比, カナダでは体積比）の圧縮強度 をセメントのみを用いたモルタルの圧縮強度で割った值

(\%)」で表わされ, 試験条件や使用セメントを同じに 保った場合には，その条件下における各種のスラグ微粉 末の相対的な活性度の評価を行うことができる. また， 限られた条件下では，この活性度指数によって，スラグ 微粉末を用いたコンクリートの強度発現性状をある程度 予測することも可能である ${ }^{1)}$.しかしながら，スラグ微

* 正会員 工修 (株) 大林組技術研究所 （市204 清瀬市下清戸4-640）

** 正会員 工博 筑波大学助教授 構造工学系 （テ305 つくば市天王台 1-1-1）
粉末を用いたコンクリートの強度発現性状は, 多くの要 因の影響を多大に受け, 特に, スラグ微粉末によるセメ ントの置換率や養生温度の影響が大きいことが多くの研 究結果に示されているのである2),31. したがって，スラ グ微粉末による置換率を一定 $(50 \%)$ に保ちながら, 常 温 (約 $20^{\circ} \mathrm{C}$ ) で養生したモルタルの試験結果から求め る現在の活性度指数は, 各種の条件下で使用されるスラ グ微粉末の活性度を一般的に評価する指標であるとはい いがたい.

本研究では, まず, スラグ微粉末の種類と置換率, 養 生温度, 材令, 等を変化させたモルタルの圧縮強度試験 を行った. 次いで，この試験結果をもとに，モルタルの 強度に及ぼす各要因の影響を順次解析して, それぞれの 要因の影響を定量的，かつ，総合的に評価できる評価式 を導いた。 また，この評価式に含まれる 2 個の係数が, スラグ微粉末による置換率, 養生温度, 材令などに左右 されないスラグ微粉末固有の活性度を表わす特性值であ ることを見出し，これらをスラグ微粉末の活性度を評価 する新たな指標として用いることを提案した。

\section{2. 使用材料}

試験には，2 種類の水砕スラグ（KO および $\mathrm{B} ）$ を粉 砕機構の相違する $2 つ$ タイプの粉砕機（ジェットミル 


\section{表一1 スラグ微粉末の物理的性質および化学成分}

\begin{tabular}{|c|c|c|c|c|c|c|c|c|c|c|c|c|c|c|c|}
\hline \multirow[t]{2}{*}{ 記号 } & \multirow[t]{2}{*}{ 比重 } & \multirow{2}{*}{$\begin{array}{c}\text { 比表面積*1 } \\
\left(\mathrm{cm}^{2} / \mathrm{g}\right)\end{array}$} & \multicolumn{3}{|c|}{ 化 } & \multicolumn{3}{|c|}{ 成 } & \multicolumn{2}{|c|}{ 分 } & \multicolumn{3}{|l|}{$(\%)$} & \multirow{2}{*}{ 塩基度 } & \multirow{2}{*}{$\begin{array}{l}\text { 強熱減 } \\
\text { 量 }(\%) \\
\end{array}$} \\
\hline & & & $\mathrm{CaO}$ & $\mathrm{SiO}_{2}$ & $\mathrm{Al}_{2} \mathrm{O}_{3}$ & $\mathrm{Mg} 0$ & $\mathrm{SO}_{3}$ & $\mathrm{TiO}_{2}$ & $S$ & $\mathrm{MnO}$ & $\mathrm{Fe}_{2} \mathrm{O}_{3}$ & $\mathrm{~K}_{2} \mathrm{O}$ & $\mathrm{Na}_{2} \mathrm{O}$ & & \\
\hline KO 5 & 2.90 & $7000(5380)$ & \multirow{3}{*}{42.9} & \multirow{3}{*}{33.9} & \multirow{3}{*}{13.1} & \multirow{3}{*}{6.5} & \multirow{3}{*}{$-\cdots$} & \multirow{3}{*}{0.75} & \multirow{3}{*}{0.9} & \multirow{3}{*}{0.67} & \multirow{3}{*}{---} & \multirow{3}{*}{0.34} & \multirow{3}{*}{0.45} & \multirow{3}{*}{1.85} & \multirow{3}{*}{+0.48} \\
\hline $\mathrm{KO} 3$ & 2.90 & $10110(8180)$ & & & & & & & & & & & & & \\
\hline $\mathrm{KO} 1$ & 2.90 & $11540(9820)$ & & & & & & & & & & & & & \\
\hline B 3 & 2.90 & $6260(3650)$ & 42.49 & 33.23 & 15.09 & 6.00 & 0.13 & 1.07 & 0.70 & 0.74 & 0.46 & 0.45 & 0.23 & 1.913 & +0.26 \\
\hline B 5 & 2.90 & $10040(6000)$ & 43.03 & 32.45 & 14.77 & 5.85 & 0.70 & 1.05 & 0.73 & 0.61 & 0.51 & 0.45 & 0.25 & 1.961 & +0.29 \\
\hline B 8 & 2.90 & $12530(7710)$ & 42.75 & 32.95 & 15.24 & 5.89 & 0.51 & 1.07 & 0.73 & 0.65 & 0.39 & 0.45 & 0.24 & 1.939 & +0.60 \\
\hline
\end{tabular}

表一2 セメントの物理的性質および化学成分

\begin{tabular}{|c|c|c|c|c|c|c|c|c|c|c|c|}
\hline \multirow[t]{2}{*}{ 記号 } & \multirow[t]{2}{*}{ 比重 } & \multirow{2}{*}{$\begin{array}{c}\text { 比表面積* } \\
\left(\mathrm{cm}^{2} / \mathrm{g}\right) \\
\end{array}$} & \multicolumn{3}{|c|}{ 化 } & 成 & \multicolumn{4}{|c|}{$(\%)$} & \multirow{2}{*}{$\begin{array}{l}\text { 強熱減 } \\
\text { 量 }(\%)\end{array}$} \\
\hline & & & $\mathrm{CaO}$ & $\mathrm{SiO}_{2}$ & $\mathrm{Al}_{2} \mathrm{O}_{3}$ & $\mathrm{Fe}_{2} \mathrm{O}_{3}$ & $\mathrm{MgO}$ & $\mathrm{SO}_{3}$ & $\mathrm{~K}_{2} \mathrm{O}$ & $\mathrm{Na}_{2} \mathrm{O}$ & \\
\hline $\mathrm{C}$ & 3.16 & $2820 \quad(3260)$ & 64.7 & 22.0 & 5.2 & 3.0 & 1.5 & 2.0 & 0.53 & 0.28 & 1.0 \\
\hline
\end{tabular}

およびボールミル) でそれぞれ 3 段階の粉末度に粉砕し た合計 6 種類のスラグ微粉末を用いた。このうち，B シリーズの試料は, 土木学会の「コンクリート用高炉ス ラグ微粉末規格 (案)」の作成の際に用いた共通試験用 試料の一部である.これらのスラグ微粉末の物理的性質 および化学成分を表一1に示す。ただし，KO シリーズ の試料の化学成分に関しては, 粉砕中に異物が混入する おそれが全くなかったので, 粉砕前の水砕スラグの試験 結果のみを示した.

セメントには，普通ポルトランドセメントを用いた. このセメントの物理的性質および化学成分を表一2に示 す.また，試験の一部には，活性のない鉱物質微粉末と して, 豊浦標準砂をボールミルで粉砕して作製したケイ 砂粉末（比重：2.64，ブレーン值：4 $310 \mathrm{~cm}^{2} / \mathrm{g}$ ）を使 用した。細骨材には, 鬼怒川産の川砂（比重：2.60, 吸 水率: 2.17 , 粗粒率: 2.56$)$ を用いた。

\section{3. 実験方法}

モルタルの配合に関しては，結合材としてセメントの みを用いたモルタル（以下，基準モルタルとよぶ）の水 セメント比を 0.50 , 砂セメント比を 2.50 とした。この 配合は，代表的なコンクリート中のモルタル部分の配合 にほぼ等しく，土木学会規準「コンクリート用高炬スラ グ微粉末規格（案)」の試験に用いる基準モルタルの配 合でもある，微粉末を用いる場合には，この基準モル夕 ル中のセメントの体積の 30,50 , あるいは $70 \%$ をこ れ亡同体積のスラグ微粉末あるいはケイ砂粉末で置換し た.したがって，結合材，水および細骨材の量は，いず れのモルタルの場合も体積比で一定となっている.

試験の温度条件は, 5,10 および $20^{\circ} \mathrm{C}$ の 3 種類とし, 使用前 24 時間以上の材料の貯蔵, モルタルの練りまぜ, 供試体の養生，等は，すべて同一温度条件下で行った。 ただし，混和材としてケイ砂粉末を用いたモルタルの試

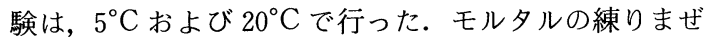

には容量約 $5 l$ のモルタルミキサを用い，1回の練りま ぜ量は $1.2 〜 2.3 l$ とした. なお, セメントの一部を微 粉末で置換する場合には，所定量のスラグ微粉末または ケイ砂粉末を所定量のセメントとともにポリエチレン袋 の中に入れ，両者をあらかじめ十分に混合してから用い た.

圧縮強度試験には， $\phi 5 \times 10 \mathrm{~cm}$ の円柱供試体を用い た。また，各試験材令における王縮強度試験には，2 バッ チから作製した 3 個の供試体を用いた。これらの供試体 のセメントペーストによるキャッピングおよび脱型は, 各供試体の積算温度がそれぞれ 15 および 30 DD となる 時期に行った，脱型した供試体は，ただちにそれぞれの 試験温度に保った水槽の中に入れ，所定の材令まで養生 した. モルタルの圧縮強度試験材令には，3，7，28 お よび 91 日の 4 水準を選んだ.

\section{4. 実験結果および実験結果の解析}

表一3に，スラグ微粉末を用いたモルタル（以下，ス ラグモルタルと略称）の圧縮強度試験結果を一覧表にし て示した. また, 図一1は, 表一3の中から代表的な試 験結果を選び，スラグモルタルの材令と圧縮強度の関係 を例示したものである.この例にも示されているように， スラグモルタルの強度が, 使用するスラグ微粉末の粉末 度や置換率, 材令, 養生温度, 等の違いにより著しく相 違することが本研究の実験でも確認された。このような 強度の差異は, 主として, モルタル中の結合材の水和反 応（あるいはペースト部分の硬化性状）が各種の要因の 影響を受けた総合的な結果としてもたらされたものと考 えられる. 本研究では, この点に着目して, 試験結果を 要因別に順次解析していくことにした，なお，配合を 3. で述べたように定めたモルタルの試験結果を用いる ため, 以下の解析と考察は, 基準モルタルの水セメント 比がある值（たとえば，50\%）に固定されていると想定 して行う。 
表一3 モルタルの圧縮強度試験データ*1

(単位 $: \mathrm{kgf} / \mathrm{cm}^{2}$ )

\begin{tabular}{|c|c|c|c|c|c|c|c|c|c|c|c|c|c|c|}
\hline \multicolumn{3}{|c|}{ 高炬スラグ微粉末 } & \multicolumn{4}{|c|}{$20^{\circ} \mathrm{C}$} & \multicolumn{4}{|c|}{$10^{\circ} \mathrm{C}$} & \multicolumn{4}{|c|}{$5^{\circ} \mathrm{C}$} \\
\hline 種 類 & $\begin{array}{l}\text { 比表面積 } \\
\left(\mathrm{cm}^{2} / \mathrm{g}\right)\end{array}$ & $\begin{array}{l}\text { 置換率 } \\
(\%)^{* 4}\end{array}$ & 3日 & 7日 & 28日 & 91日 & 3 日 & 7日 & 28日 & 91日 & 3 日 & 7日 & 28日 & 91日 \\
\hline なし・2 & $2820^{\circ} 3$ & 0 & 202 & 327 & 459 & 542 & 117 & 258 & 436 & 526 & 77 & 204 & 414 & 505 \\
\hline \multirow{2}{*}{ К $О 5$} & \multirow{2}{*}{7000} & 50 & 97 & 199 & 448 & 570 & 38 & 123 & 327 & 473 & 21 & 79 & 282 & 459 \\
\hline & & 70 & 85 & 220 & 405 & - & - & - & - & - & 13 & 67 & 266 & - \\
\hline \multirow{3}{*}{ KO 3} & \multirow{3}{*}{10110} & 30 & - & 308 & 529 & - & - & 212 & 459 & - & - & 147 & 421 & - \\
\hline & & 50 & 153 & 313 & 533 & 642 & 58 & 190 & 476 & 571 & 33 & 127 & 403 & 571 \\
\hline & & 70 & 156 & 325 & 542 & - & - & 180 & 419 & - & 24 & 110 & 382 & - \\
\hline \multirow{3}{*}{ К O 1} & \multirow{3}{*}{11540} & 30 & - & 327 & 533 & $\overline{-}$ & $\overline{-}$ & 218 & 453 & - & - & 150 & 427 & $\overline{-}$ \\
\hline & & 50 & 176 & 353 & 546 & 640 & 65 & 221 & 473 & 571 & 32 & 137 & 440 & 586 \\
\hline & & 70 & - & 369 & 562 & 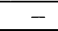 & - & 217 & 459 & - & - & 130 & 435 & - \\
\hline \multirow{2}{*}{ B 3} & \multirow{2}{*}{6260} & 30 & - & 212 & 396 & - & - & 155 & 331 & - & - & 112 & 303 & - \\
\hline & & 50 & 87 & 159 & 377 & 508 & 38. & 107 & 265 & 383 & 23 & 76 & 225 & 364 \\
\hline B 5 & 10040 & 50 & 124 & 250 & 438 & 544 & 53 & 163 & 399 & 525 & 28 & 109 & 370 & 513 \\
\hline \multirow{2}{*}{ B 8} & \multirow{2}{*}{12530} & 50 & 164 & 364 & 559 & 598 & 67 & 220 & 487 & 533 & 34 & 139 & 460 & 569 \\
\hline & & 70 & - & 343 & 509 & - & - & 213 & 458 & - & - & 128 & 431 & - \\
\hline
\end{tabular}

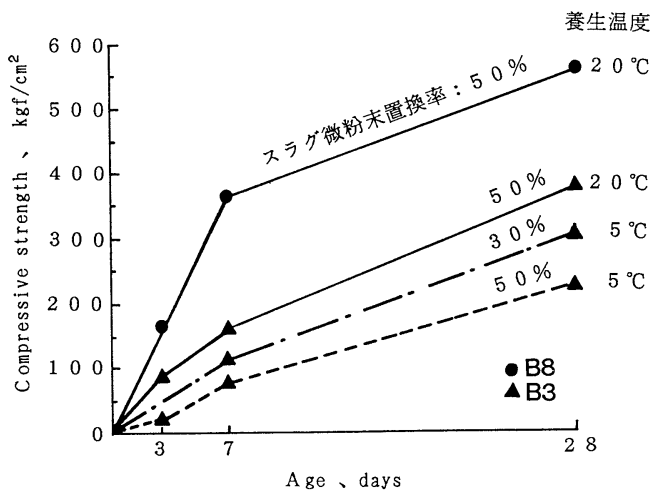

図一1 スラグモルタルの強度試験結果の一例

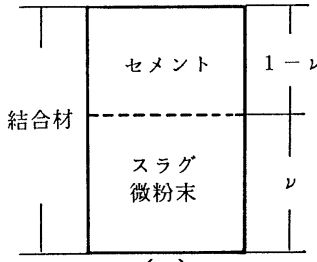

(a)

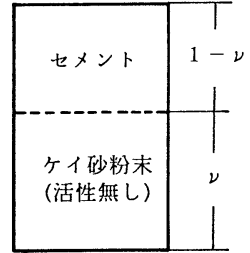

(b)
図一2 モルタル中の結合材の模式図

（1） スラグ微粉末による置換率の影響の定式化

セメントの一部をスラグ微粉末で置換したモルタルあ るいはコンクリート中の結合材は, スラグ微粉末による

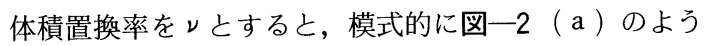
に表わすことができる．そして，これらの結合材による 強度発現は, 各結合材の強度増進効果が総合された形で もたらされると考えられる。しかしながら，セメントお よびスラグ微粉末が強度発現に寄与する効果に関して は，単に個々の寄与効果が不明であるだけでなく，それ ぞれの結合材の効果を総合して評価する手法も確立され ていないのが現状である。ここで，まず，図一2（a ）

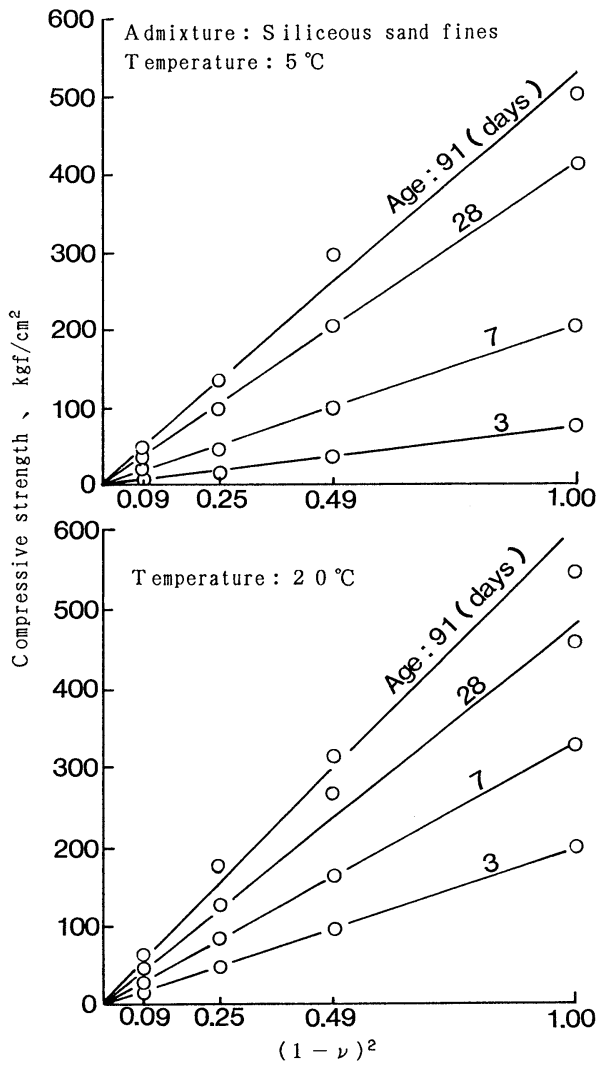

図一3 $(1-\nu)^{2}$ と圧縮強度の関係

に示されているセメント部分のみが強度発現に寄与する 効果を調べることにし，図一2（b）のように，スラグ 微粉末の代わりに活性のないケイ砂粉末でセメントの一 部を置き換えたモルタルの圧縮強度を試験した。

図一3 は，結合材中のセメントの体積割合 $(1-\nu)$ を パラメーターとして，この二乗を横軸にとり，ケイ砂粉 
末を用いたモルタルの圧縮強度試験結果を養生温度別に プロットしたものである. この図を参照すると, 長期材 令の場合にはやや適合性が悪くなる傾向にあるものの, 各材令ごとの両者の関係は, いずれの温度で養生した場 合も，原点を通る直線で近似できることが認められる. この結果より，スラグ微粉末の代わりに活性のないケイ 砂粉末を用いたモルタルの圧縮強度 $\left(f_{0}\right)$ は, 結合材中 のセメントの体積割合 $(1-\nu)$ を用いて, 式 (1) で表 わし得ると考えることにした。

$$
f_{0}=\left[K_{c}(1-\nu)\right]^{2}
$$

ここで, $K_{c}$ ：セメントが強度増進に寄与する効果を表 わす係数（温度や材令により異なる）

なお，山崎の研究4)によれば，活性を有しない微粉末 であっても，これをコンクリートに添加すると，「微粉 末効果」によりセメントの水和の程度が若干増加するこ とが示されているが，ケイ砂粉末を用いた実験から得ら れた式（1）にはこの影響も含まれていると考えること ができる.

式（1）で $\nu=0$ とおけば， $f_{0}$ は基準モルタルの強度 $\left(f_{b}\right)$ となり, $K_{c}$ は次式で表わされる.

$$
K_{c}=\sqrt{f_{b}} \ldots
$$

スラグモルタルの圧縮強度は, 式 (1) 中の [ ] の 中にスラグ微粉末の使用による強度増加に関する項を付 け加えることで表わせると考えられる. また，この場合 に付加する項は, セメントの場合と同様に, 結合材中の
スラグ微粉末の割合 $(\nu)$ の関数であると推測される. そこで, 次に, スラグ微粉末の使用による強度増加に関 する項を $K_{s v}$ として, この場合のモルタルの圧縮強度 $\left(f_{m}\right)$ を表わす式を式（3) のように仮定した. そして, この式を変形した式 (4) 中に図一3あるいは式 (2) より求まる $K_{c}$ および表一 3 の圧縮強度デー夕 $\left(f_{m}\right)$ を 代入して, $K_{s v}$ を逆算し， $K_{s v}$ の值と結合材中のスラグ 微粉末の割合 $(\nu)$ との関係について調べてみた.

$$
\begin{aligned}
& f_{m}=\left[K_{c}(1-\nu)+K_{s v}\right]^{2} \cdot \\
& K_{s v}=\sqrt{f_{m}}-K_{c}(1-\nu) \cdot
\end{aligned}
$$

ここで, $f_{m}$ : スラグモルタルの圧縮強度 $1-\nu:$ 結合材中のセメントの体積割合

図一4は，この結果を各スラグ微粉末ごとに示したも のである.これらの図によれば，いずれのスラグ微粉末 の場合にも，それぞれの養生温度および材令における $K_{s v}$ と $\nu$ との関係は，原点を通る一次式で近似できるこ とが認められる。したがって，両者の関係は式（5）で 表わすことができる.

$K_{s v}=K_{s} \nu$

ここで, $K_{s}$ ：スラグ微粉末が強度増進に寄与する効果 を表わす係数（温度や材令により異なる）

式（5）を式（3）に代入すると, 次式が得られる. $f_{m}=\left[K_{c}(1-\nu)+K_{s} \nu\right]^{2}$

以上のようにして求まった式 ( 6 ) は, スラグ微粉末 による置換率とスラグモルタルの圧縮強度の関係を表わ
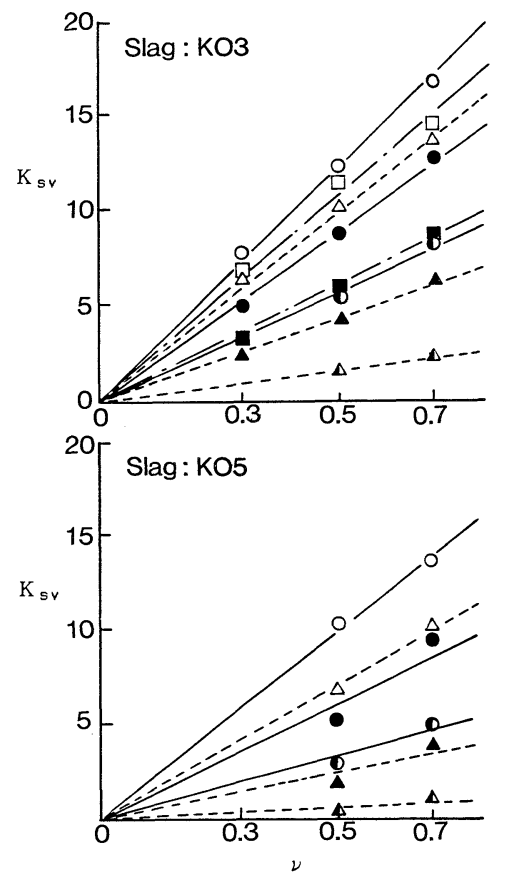
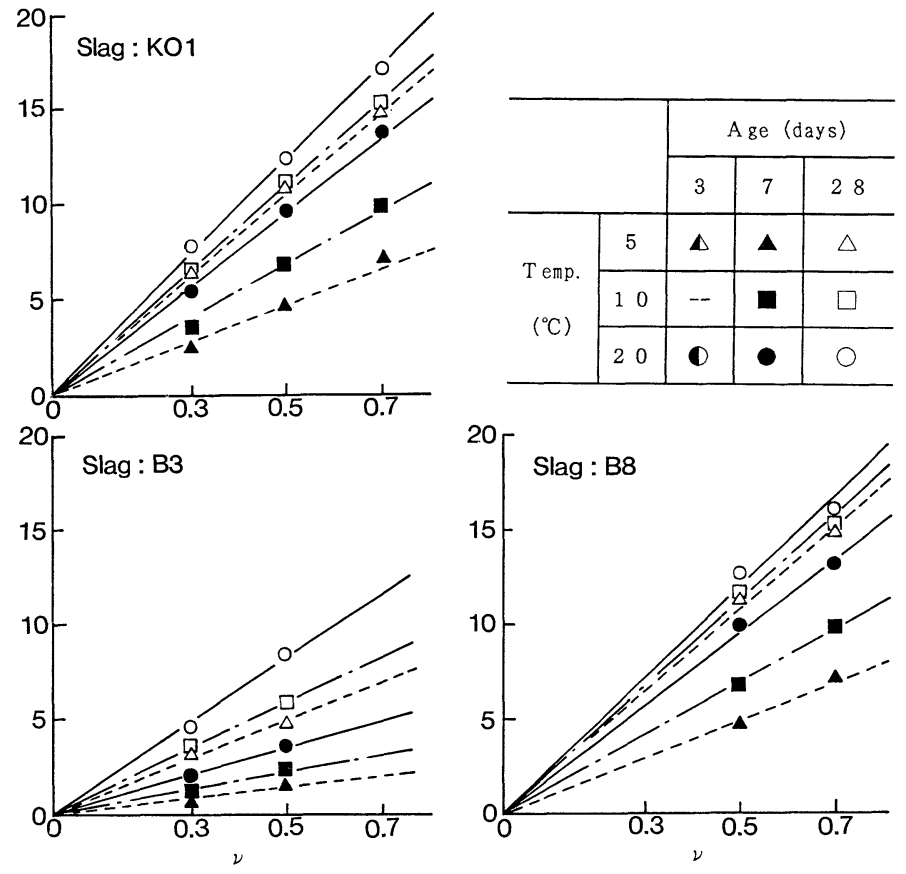

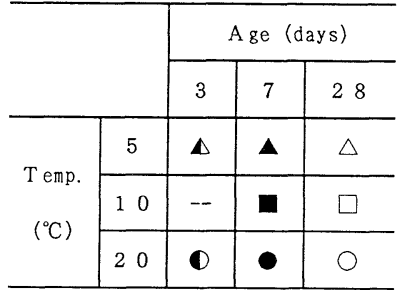

図一4 $K_{s v}$ と $\nu$ の関係 $\left(K_{s v}\right.$ の単位 $\left.: \sqrt{\mathrm{kgf} / \mathrm{cm}^{2}}\right)$ 
す一般式と考えることができ, 養生温度や材令の影響は, 式中の $K_{c}$ および $K_{s}$ の中で考慮されることになる. ま た， $K_{c}$ および $K_{s}$ は，それぞれ，七メントおよびスラ グ微粉末が全体の強度に寄与する効果の程度を表わす係 数であって, 各結合材の活性度にも関連した量であると 考えることができる.

\section{（2）養生温度および材令の影響の定式化}

表一4 は，本研究で用いたすべての結合材について， 上述してきた関係式を利用して求めた $K_{c}$ および $K_{s}$ の 值を示したものである.これらの值は, 当然のことなが ら, 結合材の種類, 養生温度, 材令などによって相当に 相違している. そこで, 次に, 養生温度と材令が $K_{c}$ お よび $K_{s}$ の值に及ぼす影響を積算温度の考え方を適用し て検討してみた．積算温度 $(M)$ は，材令と養生温度 の要因を組み合わせた関数であり，一般には式（7）に より表わされる.

$$
M=\sum t(\theta+10)
$$

ここで, $t:$ 材令 $($ 日 )

$$
\theta: \text { 養生温度 }\left({ }^{\circ} \mathrm{C}\right)
$$

図一 5 は，表一 4 に示した各養生温度および材令にお ける $K_{c}$ の值を, 式 $(7)$ で計算したそれぞれの積算温 度 $(M)$ に対してプロットしたものである.また，図 一6は，図-5 と同じ関係を各スラグ微粉末別に示した ものである.まず, 図一5を参照すると, 両者の関係は, 養生温度に関係なく，1 本の曲線で表わされることが認 められる. そして, $K_{c}$ の值は, 積算温度のごく小さい 範囲で急激に増加しているが，その増加率は積算温度の 増大とともに漸減する傾向にある。一方，図一6に示し た各スラグ微粉末の $K_{s}$ と積算温度の関係は, 上記の $K_{c}$ の場合と同様な曲線で近似できるものの，養生温度 の違いによって曲線が若干相違することが羿められる. また，いずれのスラグ微粉末を用いた場合も， $20^{\circ} \mathrm{C}$ 養 生に対する曲線が原点を通っているのに対し， $5^{\circ} \mathrm{C}$ お び $10^{\circ} \mathrm{C}$ の低温度下で養生した場合の曲線は, 原点より も若干右へシフトした位置で横軸と交わる傾向にある. これらの養生温度の違いによる曲線の相違は, スラグ微 粉末の活性の温度依存性がセメントよりも大きいことを 示唆するものと考えられる.
図一 5 および図一6に認められる $K_{c}$ あるいは $K_{s}$ の値 （以下，これらを総じる場合は $K$ 值と称す）と積算温 度 $(M)$ の関係は，一般的には図一7に示すような曲線 モデルで表わすことができると考えられる.本研究では， このモデルの定式化にあたって, 式（８）の適用を試み

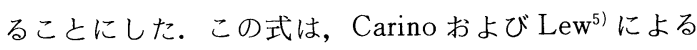
強度-積算温度の関係式を， $K$ 值-積算温度関係に準用 したものである。

$$
K=\frac{M-M_{0}}{\frac{1}{a}+\frac{M-M_{0}}{b}}
$$

式（8）は, 初期の接線勾配 $a$, 縦軸上の極大值 $b$, および横軸との交点 $M_{0}$ によって決定される双曲線を表 わす式である.したがって，式（８）を適用することの 妥当性が確認されれば，この式は結合材の活性度を評価 するためにきわめて都合の良い式といえる．すなわち， $a$ は, 積算温度のごく小さい範囲で $K$ 値が増大する程 度を示す值であるので, 結合材がモルタルの初期の強度 発現に寄与する効果を表わす特性值になり得ると考えら れる．また， $b$ は，積算温度がきわめて大きくなった場 合の $K$ 值の最大值に対応することから, 結合材がモル タルの最終的な強度の大きさに寄与する効果を表わす特 性值と考えることができる.

一方， $M_{0}$ は，各結合材が強度発現に実質的に寄与し 始める時点までの積算温度を示す量と考えられる．この $M_{0}$ の概略值は，図一 5 および図一 6 から読み取ることも

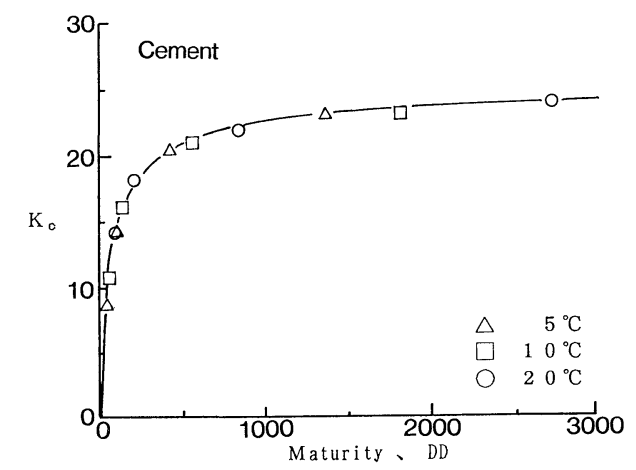

図一 5 積算温度 $(\boldsymbol{M})$ と $\boldsymbol{K}_{c}$ の関係 $\left(K_{c}\right.$ の単位 $\left.: \sqrt{\mathrm{kgf} / \mathrm{cm}^{2}}\right)$

表一4 セメントの $\boldsymbol{K}_{c}$ および各スラグ微粉末の $\boldsymbol{K}_{s}$

(単位 $: \sqrt{\mathrm{kgf} / \mathrm{cm}^{2}}$ )

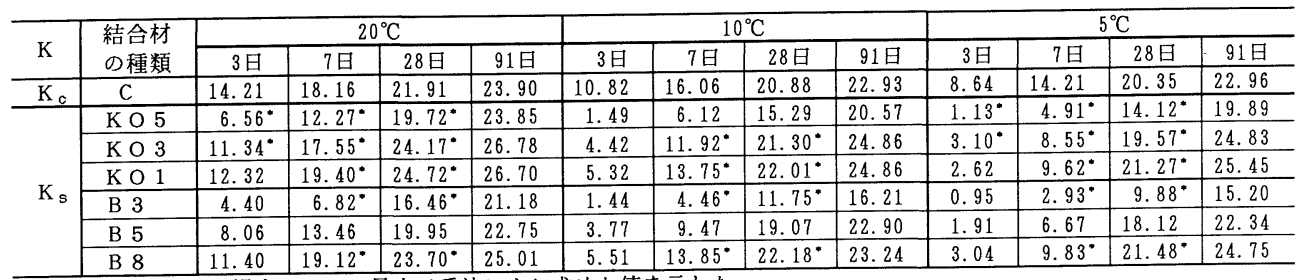

*置換率の異なる場合について最小二乗法により求めた值を示した。 

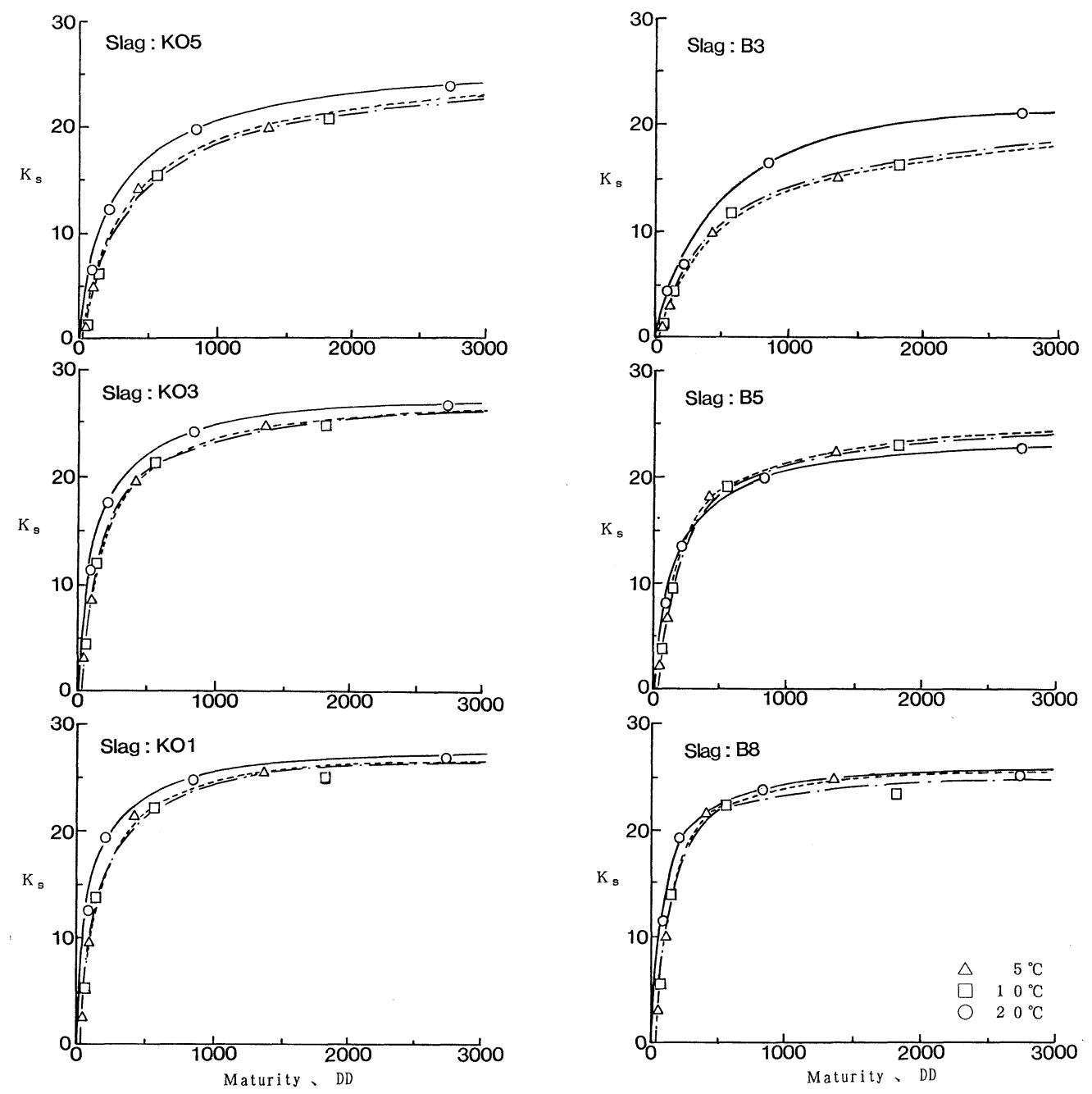

図一 6 積算温度 $(\boldsymbol{M})$ と $\boldsymbol{K}_{s}$ の関係 $\left(K_{s}\right.$ の単位 $\left.: \sqrt{\mathrm{kgf} / \mathrm{cm}^{2}}\right)$

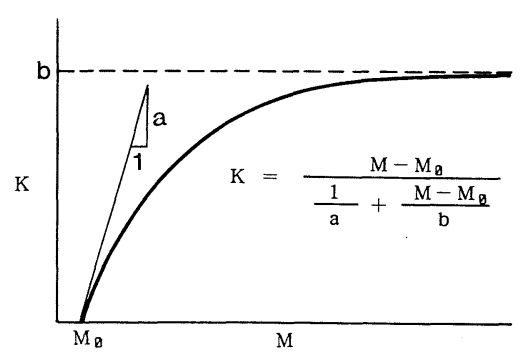

図-7 $\quad \boldsymbol{K}$ 值-積算温度 $(\boldsymbol{M})$ 関係の模式図

可能である. しかし, ここでは, 式（8）の適用を試み ているため, この式に最小二乗法を適用して, すべての 場合に対する $M_{0}$ の值を求めてみた. その結果, セメン トに対する $M_{0}$ の值は, 養生温度に関係なく, すべて 0 DDであった。 また， スラグ微粉末に対する $M_{0}$ は，そ
の種類に関係なく, $20^{\circ} \mathrm{C}$ で養生した場合にはほぼ $0 \mathrm{DD}$, 低温度下 $\left(5\right.$ および $\left.10^{\circ} \mathrm{C}\right)$ で養生した場合は, 約 30 DD となった. これらの結果を考虑に入れ，セメントお よびスラグ微粉末に対する $K$ 值を求める式を表わすと, それぞれ，式（9）および（10）のようになる.

$$
\begin{gathered}
K_{c}=\frac{M}{\frac{1}{a_{c}}+\frac{M}{b_{c}}} \cdots \cdots \\
K_{s}=\frac{M-M_{0}}{\frac{1}{a_{s}}+\frac{M-M_{0}}{b_{s}}}
\end{gathered}
$$

ここで,

$a_{c}$ : セメントが初期の強度発現に寄与する効果を表わ す特性值

$a_{s}$ : スラグ微粉末が初期の強度発現に寄与する効果を 表わす特性値 
$b_{c}$ : セメントが最終的な強度に寄与する効果を表わす 特性值

$b_{s}$ : スラグ微粉末が最終的な強度に寄与する効果を表 わす特性值

$M_{0}: 0(\mathrm{DD})$ $20^{\circ} \mathrm{C}$ 養生の場合

30 (DD) $5^{\circ} \mathrm{C}$ および $10^{\circ} \mathrm{C}$ 養生の場合

図一7 の曲線モデルに適用した式（8）を式（11）の ように変形すると, $\left(M-M_{0}\right) / K$ と $\left(M-M_{0}\right)$ の関係 は図一8に示すような直線になり，この直線の縦軸との 切片と勾配から $a$ および $b$ の值を容易に求めることが できる.

$\frac{M-M_{0}}{K}=\frac{1}{a}+\frac{M-M_{0}}{b}$

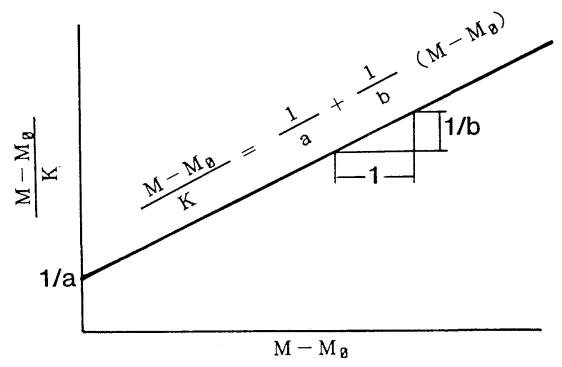

図-8 $\left[\left(\boldsymbol{M}-\boldsymbol{M}_{0}\right) / \boldsymbol{K}\right]$ と $\left(\boldsymbol{M}-\boldsymbol{M}_{0}\right)$ の関係
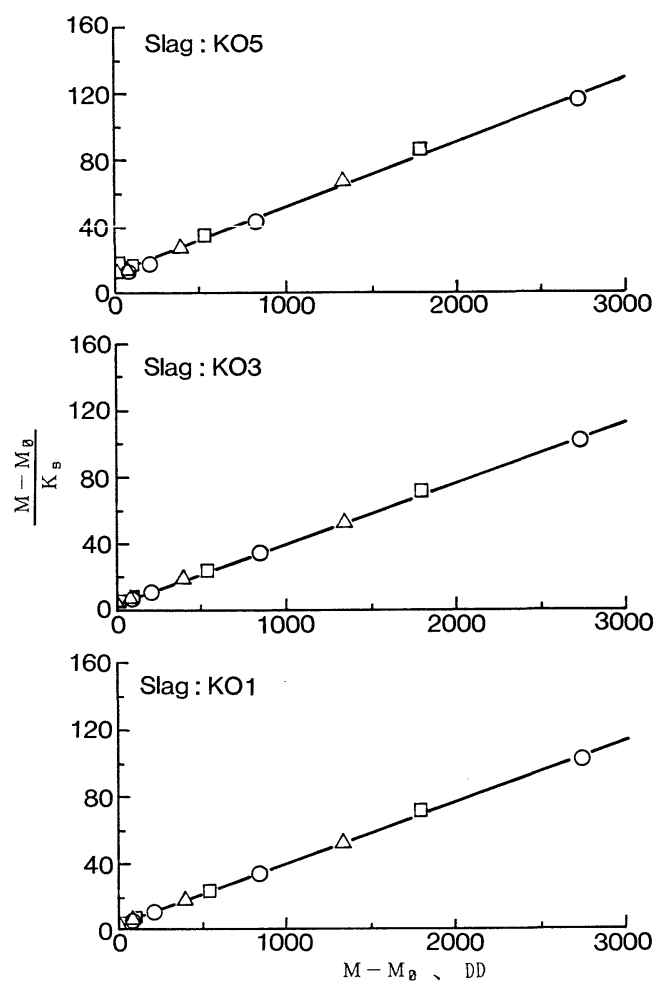

そこで, 式 ( 8 ) の適用性と上記の $M_{0}$ の值の妥当性 を調べるために，式（9）および（10）を式（11）の形 に変形し，各結合材ごとに示した先の $K$ 值と積算温度 $(M)$ の関係を, $M / K_{c}$ と $M$ の関係ならびに $\left(M-M_{0}\right)$ $/ K_{s}$ と $M-M_{0}$ の関係で整理し直してみた.この結果を 図一 9 および図一10に示す。これらの図によれば，いず れの結合材の場合も, 図一6に示されたような養生温度 の違いによる相関関係の相違はなく，両者の関係は 1 本 の直線で表わせることが認められる. また, 個々の值は, 最小二乗法によって求めた図中の直線ときわめて良く一 致していることも認められる.これらは, 本研究の試験 結果のモデル化にあたって適用を試みた前記の式（8） がきわめて適切な式であることを証明するとともに，

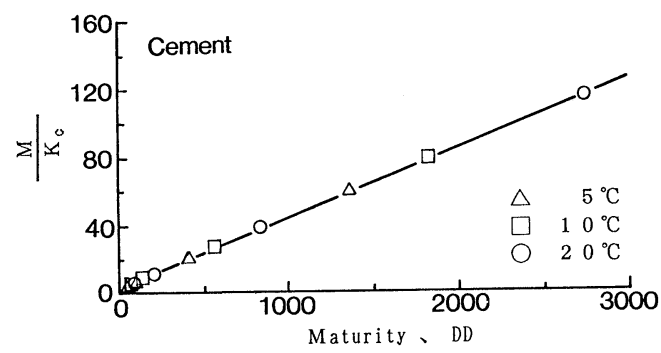

図—9 $\boldsymbol{M} / \boldsymbol{K}_{0}$ と $\boldsymbol{M}$ の関係 $\left(\boldsymbol{M} / \boldsymbol{K}_{\boldsymbol{c}}\right.$ の単位 $\left.: \mathrm{DD} / \sqrt{\mathrm{kgf} / \mathrm{cm}^{2}}\right)$
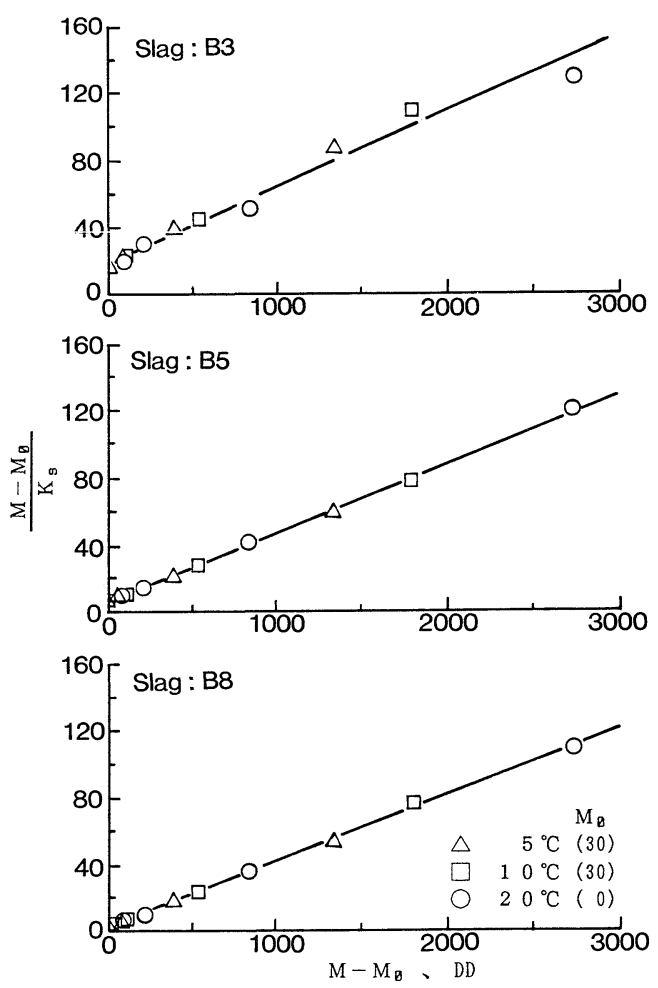

図-10 $\left[\left(\boldsymbol{M}-\boldsymbol{M}_{0}\right) / \boldsymbol{K}_{s}\right]$ と $\left(\boldsymbol{M}-\boldsymbol{M}_{0}\right)$ の関係 $\left[\left(\boldsymbol{M}-\boldsymbol{M}_{0}\right) / K_{s}\right.$ の単位 $\left.: \mathrm{DD} / \sqrt{\mathrm{kgf} / \mathrm{cm}^{2}}\right]$ 
$K_{c}$ および $K_{s}$ の算定に式（9）および式（10）が精度良 く適用できることを示すものと考えられる.

以上の解析を通じて, セメントおよびスラグ微粉末が モルタルの強度に寄与する効果を表わす $K_{c}$ および $K_{s}$ は, 材令と養生温度の関数である積算温度 $(\boldsymbol{M})$ を用 いて整理でき，それぞれ式（9）および式（10）で表示 できることが明らかとなった. なお, 本研究で対象とし なかった温度範囲における $M_{0}$ の値に関しては, 試験結 果がないので断定はできないが，少なくとも $20^{\circ} \mathrm{C}$ 以上 の場合は 0 (DD) で良いと考えられる. また, 温度 $(\theta)$ が $10 \sim 20^{\circ} \mathrm{C}$ の間の場合には, $M_{0}=60-3 \theta$ の式で比例 近似しても結果に大きな差異は生じないと思われる.

\section{（3） スラグ微粉末の活性度の評価指標}

前記の式( 9 )および(10)中の $a_{c}, b_{c}, a_{s}$ および $b_{s}$ は, 基準とするモルタルの水セメント比が変われば, 変化す る值である. しかし, 基準モルタルの水セメント比が変 わっても, これらが初期材令と長期材令の双方における 強度発現に寄与する結合材の効果を表わす特性值である ことには変わりがない. また，これらの特性值は，スラ グ微粉末の置換率, 材令, 養生温度, などによって変化 しない特徵を有している. さらに, これらの值を前記の 式 (9) および (10)に代入して $K$ 值を求めれば, 式 (6) によって, 任意の材令, 養生温度あるいはスラグ微粉末 の置換率に対しても, モルタルの強度が算出できる量で もある.これらの諸点を考慮すると, 上記の特性値は, それぞれの結合材に固有な活性を表わす量と考えること ができると思われる. このような特性值を, すべての結 合材について求めた結果をまとめて示したのが表一5で ある・

上記のように, $a_{c}, b_{c}, a_{s}, b_{s}$, 等が各結合材に固 有の值であると仮定すると, 同じ原料を粉砕して作製し た各スラグ微粉末の $a_{s}$ の值は, それぞれの比表面積の 值に比例すると考えられる. この点を確認するために, 各スラグ微粉末の $a_{s}$ と比表面積の值をセメントの值に 対する比 $\left(a_{s} / a_{c}, S_{v s} / S_{v c}\right)$ で表わし, 両者の関係を プロットしてみた.この場合の比表面積の值としては,

\section{表一 5 各結合材の活性を表わす特性値}

(単位： $a$ は $\sqrt{\mathrm{kgf} / \mathrm{cm}^{2}} / \mathrm{DD}$ $b$ は $\left.\sqrt{\mathrm{kgf} / \mathrm{cm}^{2}}\right)$

\begin{tabular}{l|c|c}
\hline セメント & $\mathrm{a}_{c}$ & $\mathrm{~b}_{c}$ \\
\hline $\mathrm{C}$ & 0.308 & 24.33 \\
\hline \multicolumn{3}{|c}{} \\
\hline スラグ微粉末 & $\mathrm{a}_{s}$ & $\mathrm{~b}_{s}$ \\
\hline K O 5 & 0.076 & 26.04 \\
\hline K O 3 & 0.188 & 27.78 \\
\hline K O 1 & 0.228 & 27.55 \\
\hline B 3 & 0.049 & 22.88 \\
\hline B 5 & 0.145 & 24.51 \\
\hline B 8 & 0.266 & 25.71 \\
\hline
\end{tabular}

レーザー光法による粒径分布の測定結果から計算した值 を用いた.これは, 原材料や粉砕方法が相違する微粉末 あるいは比表面積が非常に大きい微粉末の比表面積を評 価する場合には, ブレーン法の適用は不適であって,レー ザー光法を採用した方が実際に近い值が得られるという 著者らの研究結果 ${ }^{6)}$ に基づくものである. $a_{s} / a_{c}$ と $S_{v s} / S_{v c}$ の関係を示した図一11 を参照すると, $a_{s} / a_{c}$ は $S_{v s} / S_{v c}$ の増加とともに直線的に増大しており，予期し た比例関係が認められる. なお， $a_{s} / a_{c}$ の值は，いずれ のスラグ微粉末の場合も 1.0 より小さい範囲にあり, モ ルタルあるいはコンクリートのごく初期の強度発現に寄 与する効果をセメントの場合と同等にするためには, ス ラグ微粉末の比表面積をセメントの值の約 4.5 倍にも増 大させる必要のあることも認められる.

一方, 同一原料から作製したスラグ微粉末の $b_{s}$ の值 は,この值の性格上, 比表面積の大小にかかわらずほぼ 一定の值となるのが自然といえる．表一 5 の $b_{s}$ の值を 参照すると，各シリーズ (KO および B ) 内では互いに ほぼ同じ值になっており, 妥当な結果が示されている. また, $b_{s}$ の值は, 全般的にセメントの值 $\left(b_{c}\right)$ より大 きくなっており, スラグ微粉末の使用が長期強度の増進 に役立つという一般の試験結果を裏付けてもいる.これ らの結果は, $a_{s}$ および $b_{s}$ が, 単に各スラグ微粉末に固 有な值であるだけでなく, スラグ微粉末の活性特性を表 わす合理的な優れた指標であることを示すものと思われ る.

上記のような有用な特性值は，基準モルタルおよびス ラグモルタルについて, それぞれ 3〜4 材令で強度試験 を行い, 図一10のような直線関係を利用して容易に求 めることができる.この場合， $\left(M-M_{0}\right)$ の值ができる だけ広範に分布するように試験温度と材令を選定するこ とが望ましいが, 基準モルタルとスラグモルタルの強度 を同じ積算温度 $(M)$ で試験することさえ注意すれば,

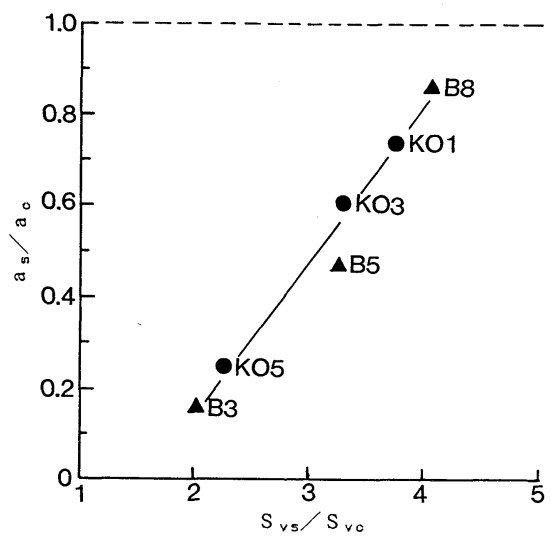

図一11 $\boldsymbol{S}_{v s} / \boldsymbol{S}_{v c}$ と $\boldsymbol{a}_{s} / \boldsymbol{a}_{c}$ の関係 
試験材令と試験温度は任意に設定して良いのである。ま た，スラグ微粉末による置換率も， $50 \%$ 程度が望まし いと思われるが，任意に設定できる．このような試験の 簡便さと前述の合理的な特性を考慮して，本研究では， $a_{s}$ をスラグ微粉末の初期活性係数， $b_{s}$ をスラグ微粉末 の長期活性係数と呼称し，これらの係数をスラグ微粉末 の活性度を評価するための新たな指標として用いること を提案する.なお，これらの係数が使用するセメントに よって若干相違することも予想されるが，この点に関し ては, 現在各国で用いられている活性度指数の場合も同 じである.

以上に述べてきたスラグ微粉末の活性度評価方法は, 単にスラグ微粉末だけでなく，フライアッシュやシリカ フュームなどの混和材や各種セメントの相対的な活性度 を評価するための有用な方法ともなり得ると考えられ る. また，本研究の手法をさらに発展させれば，任意の 条件下におけるモルタルあるいはコンクリートの強度を 推定できる方法が確立できる可能性もある.これらの諸 点については, 今後さらに検討していく予定である.

\section{5. 結 論}

本研究の範囲内で次のことがいえると思われる.

（1）基準とするモルタル中のセメントの一部を，こ れと同体積のスラグ微粉末で置換したスラグモルタルの 圧縮強度 $\left(f_{m}\right)$ は，一般に次式で表わすことができる.

$$
f_{m}=\left[K_{c}(1-\nu)+K_{s} \nu\right]^{2}
$$

ここで,

$K_{c}$ : セメントが強度増進に寄与する効果を表わす係数

$K_{s}$ : スラグ微粉末が強度増進に寄与する効果を表わす 係数

$\nu$ : スラグ微粉末による体積置換率

( 2 ）上記の $K_{c}$ および $K_{s}$ は, 任意の養生温度 $(\theta)$ と材令 $(t)$ に対し, 次式で表わすことができる.

$$
\begin{aligned}
& K_{c}=\frac{M}{\frac{1}{a_{c}}+\frac{M}{b_{c}}} \\
& K_{s}=\frac{M-M_{0}}{\frac{1}{a_{s}}+\frac{M-M_{0}}{b_{s}}} \\
& M=\sum t(\theta+10)
\end{aligned}
$$

ここで,

$a_{c}$ ：セメントが初期の強度発現に寄与する効果を表わ す特性值

$a_{s}$ : スラグ微粉末が初期の強度発現に寄与する効果を 表わす特性值

$b_{c}$ : セメントが最終的な強度に寄与する効果を表わす 特性值 $b_{s}$ : スラグ微粉末が最終的な強度に寄与する効果を表 わす特性值

$M_{0}: 0(\mathrm{DD})$ $20^{\circ} \mathrm{C} \leqq \theta$ の場合 $60-3 \theta$ (DD) $\cdots \cdots \cdots \cdots \cdot \cdots \cdot 10^{\circ} \mathrm{C}<\theta<20^{\circ} \mathrm{C}$ の場合 30 (DD) ….............. $5{ }^{\circ} \mathrm{C} \leqq \theta \leqq 10^{\circ} \mathrm{C}$ の場合

（3）基準モルタルの水セメント比を固定し，このセ メントの一定量を, これと同じ体積のスラグ微粉末で置 換した配合を選定すれば， $a_{c}, b_{c}, a_{s}, b_{s}$ ，等の特性 值は, 次のように簡単に求めることができる.

まず，基準モルタルおよびスラグモルタルについて， 積算温度 $(\boldsymbol{M})$ の值ができるだけ広範に分布するよう に配慮しながら，それぞれに共通した $3 〜 4$ 材令で圧縮 強度試験を行い，各材令に対する $K_{c}$ および $K_{s}$ を下記 の式で計算する. 次いで, 各材令ごとに $M / K_{c}$ および $M$ の值あるいは $\left(M-M_{0}\right) / K_{s}$ および $\left(M-M_{0}\right)$ の值 を計算し，これらをそれぞれ縦軸および横軸の量として 直交座標系上にプロットする，これらの関係に最小二乗 法を適用して求まる一次式の縦軸との交点の逆数および 勾配の逆数が，それぞれ， $a_{c}$ または $a_{s}, b_{c}$ または $b_{s}$ である。

$$
\begin{aligned}
& K_{c}=\sqrt{f_{b}} \\
& K_{s}=\left[\sqrt{f_{m}}-K_{c}(1-\nu)\right] / \nu
\end{aligned}
$$

ここで, $f_{b}$ : 基準モルタルの圧縮強度

(4) $a_{c}, b_{c}, a_{s}, b_{s}$, 等の特性值は, スラグ微粉 末の置換率, 材令, 養生温度, などによって変化しない 特徴を有し，それぞれの結合材に固有な活性を表わす量 でもある。このような合理性を有する $a_{c}$ および $a_{s}$ を 初期活性係数, $b_{c}$ および $b_{s}$ を長期活性係数と呼称し, スラグ微粉末の活性度を評価する場合には，従来の活性 度指数に代わる新たな指標として $a_{s}$ および $b_{s}$ を用い ることを提案する.

謝辞：本研究の実施にあたり，住友金属工業 (株) より助成金を賜り, その大半を近松の学資の一部として 使わせて頂いた。 また，試料の粉砕およびレーザ一光に よる粒度分布の測定は，(株)セイシン企業の方々のご好 意により行うことができた.さらに，実験にあたっては， 筑波大学構造工学系技官 飯高 稔氏にご援助を頂いた. ここに付記し，厚く御礼申し上げます。

\section{参 考 文 献}

1）山本泰彦：高炉スラグ微粉末の品質規格について, コン クリートライブラリー, 第 63 号, 土木学会, pp. 107 112, 1988.

2）たとえば，遠藤裕悦・児玉和巳 - 中川 脩・高田 誠： 高炬スラグ微粉末がコンクリートの配合と強度におよぼ す影響について, 高炉スラグ微粉末のコンクリートへの 適用に関するシンポジウム論文集, 土木学会, pp. $73 \sim 80$, 
1987.

3）たとえば，今井益隆・大橋 猛・斉藤敦志：高炬スラグ 微粉末を混和したコンクリートの諸性質, 高炉スラグ微 粉末のコンクリートへの適用に関するシンポジウム論文 集, 土木学会, pp. $67 \sim 72,1987$.

4）山崎寛司 : 鉱物質微粉末がコンクリートのウォーカビリ チーおよび強度におよぼす効果に関する基礎研究，コン
クリートライブラリー, 第 8 号, 土木学会, 1963.

5) Carino, N. J. and Lew, H.S. : Temperature Effect on Strength-Maturity Relations of Mortar, Journal of ACI, Vol. 80, No. 3, May-June, pp. 177 182, 1983.

6）近松竜一・山本泰彦：高炉スラグ微粉末の粉末度評価法 に関する研究, 土木学会論文集に投稿中

(1989.4.6 - 受付) 